\title{
PELATIHAN PENGELOLAAN APLIKASI SISTEM INFORMASI BAGI WARGA KELURAHAN SAWAH BARU, TANGERANG SELATAN
}

\author{
TRAINING TO MANAGE THE INFORMATION SYSTEMS APPLICATION \\ FOR CITIZENS OF SAWAH BARU, TANGERANG SELATAN
}

\author{
${ }^{1)}$ Johannes Hamonangan Siregar, ${ }^{2)}$ Chaerul Anwar, ${ }^{3)}$ Marcello Sangaji \\ ${ }^{1,2,3)}$ Program Studi Sistem Informasi, Center for Urban Studies, Universitas Pembangunan Jaya, \\ Jalan Cenderawasih, Bintaro Jaya, Sawah Baru, Ciputat, Tangerang Selatan 15413 \\ Email: johannes.siregar@upj.ac.id
}

\begin{abstract}
ABSTRAK
Kegiatan ini dilaksanakan berdasarkan adanya faktor kebutuhan warga pengguna internet untuk memperoleh pengetahuan dan keterampilan dalam mengelola aplikasi sistem informasi. Tujuan kegiatan adalah meningkatkan pengetahuan dan memberikan keterampilan pengelolaan aplikasi sistem informasi kepada warga kelurahan Sawah Baru, Tangerang Selatan. Peserta kegiatan ini adalah pemuda yang aktif dalam kepengurusan organisasi yang ada di kelurahan, sebanyak 16 orang. Metode pelaksanaan kegiatan dilakukan dengan mengadakan pelatihan dalam bentuk ceramah yang disertai peragaan pemakaian, praktek, tanya jawab dan diskusi studi kasus. Pelaksanaan kegiatan ini dibantu oleh mahasiswa dari Program Studi Sistem Informasi. Hasil kegiatan dari aspek pengetahuan diukur dengan pre tes dan pos tes, dari aspek keterampilan diukur dengan pengamatan langsung terhadap peserta dalam mengelola aplikasi melalui tanya jawab lisan, yang didapatkan hasil sebagai berikut. Pertama, peserta mendapat peningkatan pengetahuan yang dibutuhkan untuk dapat mengelola aplikasi. Kedua, peserta memperoleh keterampilan untuk mengelola aplikasi dengan benar. Kegiatan ini juga memberikan dampak baik bagi mahasiswa yang memungkinkan terjadinya kolaborasi dengan peserta dalam memberi solusi untuk kebutuhan warga.
\end{abstract}

Kata kunci: Pelatihan; Keterampilan; Aplikasi Sistem Informasi; Kolaborasi

\begin{abstract}
This activities are conducted base on the factor need of citizens whom internet user for having knowledge and skill how to manage information systems application. The purpose of this activity is to provide basic knowledge and skills how to manage information system applications for citizens of Sawah Baru, Tangerang Selatan. The participants of this activity were young people active on organization, as the number 16 participants. This activity is assisted by students of the Information Systems Study Program. The methods to conduct this activity is training in lecture with demonstration how to use, practices, question and answer then discussion for case study. The results of this activity for knowledge aspects are measured by pre test and post test, for skill aspects are measured by making direct observations of the participants asked question and written tests, as follows. First, participants get incrased knowledge needed for how to manage application. Second, participants obtained skills to manage application. This activity also has good impact for students that enable collaboration with participants in providing solutions to the needs of the community.
\end{abstract}

Keywords: Training; Skill; Information System Applications; Collaboration

Submitted : 25 Maret 2019 Revision : 20 Juni $2019 \quad$ Accepted : 14 Agustus 2019 
Johannes Hamonangan Siregar, Chaerul Anwar, Marcello Sangaji

Pelatihan Pengelolaan Aplikasi Sistem Informasi Bagi Warga Kelurahan Sawah Baru, Tangerang Selatan

\section{PENDAHULUAN}

Dalam masyarakat Indonesia, dari tahun ke tahun pengguna gadget diprediksi akan meningkat tajam. Pada tahun 2017 pengguna gadget secara online dengan memakai koneksi jaringan internet telah mencapai 143,26 juta jiwa atau $54,7 \%$ dari populasi penduduk (APJII, 2018). Prediksi peningkatan pengguna gadget secara tajam akan sangat dimungkinkan dengan memperhatikan perkembangan sistem informasi yang membuat bermacam aplikasi untuk memenuhi kebutuhan masyarakat. Pemakaian gadget diperlukan tidak hanya untuk melakukan kegiatan komunikasi tapi dibutuhkan juga untuk kegiatan ekonomi di berbagai bidang. Di bidang perdagangan, dapat memudahkan penjual dan pembeli melakukan transaksi secara online. Di bidang transportasi dapat memudahkan pemesanan kendaraan yang diperlukan secara online. Di bidang pariwisata dalam hal pemesanan akomodasi penginapan dan masih banyak bidang lain yang sedang dikembangkan untuk memenuhi kebutuhan masyarakat. Dengan demikian Kementrian Perdagangan sebagai instansi yang bertanggung jawab dalam perdagangan di Indonesia, menyatakan bahwa penguasaan informasi bukan hanya sekedar kemampuan mengumpulkan informasi saja tetapi penting juga untuk mengelola setiap informasi yang berhubungan erat dengan kepentingan bisnis (Pusat Humas Kementerian Perdagangan RI, 2014).

Di kota Tangerang Selatan, penggu-na gadget termasuk cukup tinggi, hal ini terlihat dari setiap rumah tangga yang anggotanya mempunyai handphone sebesar 78,21\% (BPS, 2017). Pengguna gadget dari Warga Kelurahan Sawah Baru, Kecamatan Ciputat, Kota Tangerang Selatan banyak yang mengunakan smartphone. Dengan mudahnya mendapatkan jaringan koneksi internet dari layanan provider, banyak aplikasi sistem informasi yang dapat digunakan oleh warga. Pengelolaan aplikasi sistem informasi untuk mempermudah warga mencapai tujuan kegiatan bersama kantor kelurahan menjadi hal yang perlu diperhatikan. Warga memiliki pemahaman yang terbatas terhadap konsep aplikasi sistem informasi, sehingga dalam pemakaian aplikasi hanya pada fungsi aplikasi yang sederhana, mudah digunakan secara cepat dan mudah diingat.

Untuk mengerti sistem informasi secara menyeluruh, haruslah diperluas pemahaman sistem informasi yang terdiri dari 3 dimensi yaitu organisasi, pengelolaan dan teknologi (Laudon \& Laudon, 2015) seperti yang ditunjukkan pada Gambar 1.

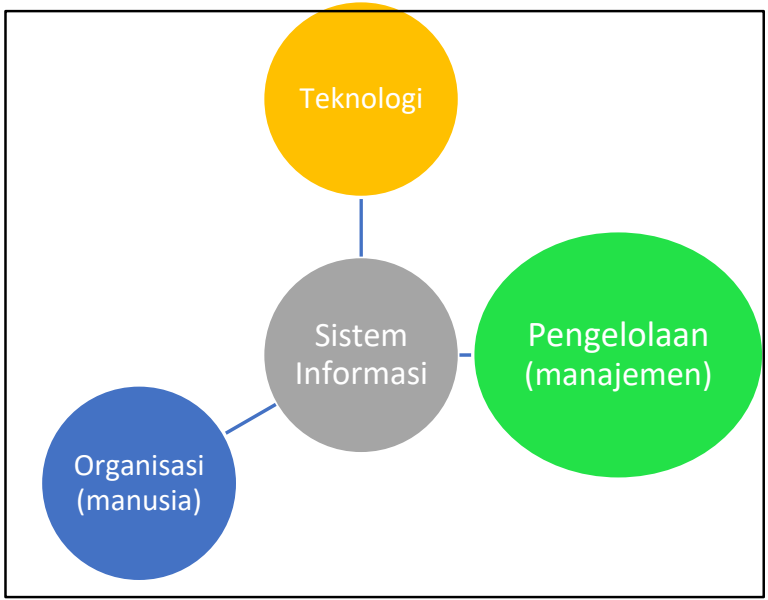

Gambar 1. Sistem Informasi terdiri 3 dimensi

Sebagai contoh sederhana pada pemakaian fungsi chat pada aplikasi WhatsApp (dimensi teknologi) banyak warga (dimensi organisasi) hanya memahami dan mengunakan fungsi tersebut terbatas untuk mengirim dan membalas berita lewat teks saja (dimensi pengelolaan). Kegunaan lain seperti pengaturan pengiriman dokumen teks, suara dan pengelolaan dokumen belum dapat dimanfaatkan. Manfaat untuk memakai fungsi yang ada dalam aplikasi memerlukan pemahaman dan pelatihan sehingga mendapatkan keterampilan pengelolaan. Selain itu jenis aplikasi sistem informasi yang banyak digunakan oleh warga adalah aplikasi untuk keperluan tukar-menukar informasi dan komunikasi secara pribadi. Warga belum memahami penggunaan aplikasi yang berkaitan dengan pendidikan anak, pencarian pekerjaan dengan online, bagaimana mendapatkan informasi dari kantor kelurahan untuk pengurusan dokumen. Sehingga kolaborasi atau 
Johannes Hamonangan Siregar, Chaerul Anwar, Marcello Sangaji

Pelatihan Pengelolaan Aplikasi Sistem Informasi Bagi Warga Kelurahan Sawah Baru, Tangerang Selatan

kerja-sama antar warga dengan warga, antar warga dengan staf kantor kelurahan dalam hal penerimaan dan penyampaian informasi dapat berjalan baik dengan bantuan aplikasi sistem informasi.

Perangkat gadget yang paling banyak dimiliki oleh warga yaitu smartphone, kesulitan pengelolaan data akan terjadi untuk jumlah data yang bertambah banyak. Pemahaman dan keterampilan menggunakan komputer dibutuhkan supaya dapat terjadi efisiensi, kecepatan mendapatkan data dan kemudahan dalam hal memperbaiki data. Salah satunya aplikasi untuk pengelolaan dokumen yang memakai aplikasi Google yaitu Google Docs dapat digunakan untuk menjadi tempat penyimpanan, berbagi dan mengakses dokumen, yang dapat diakses dari perangkat keras komunikasi seperti smartphone dan komputer. Pengelolaan dokumen tersebut jika memakai smartphone akan menemui kesulitan ketika jumlah dokumen sudah semakin banyak dengan tipe dokumen yang berbeda. Dengan mengunakan komputer pengelolaan dokumen menjadi lebih mudah, sehingga nantinya dokumen menjadi disusun teratur yang akan menjadikan mudah untuk diakses. Penggunaan aplikasi Google Docs telah banyak dilakukan dalam dunia akademik. Dengan menggunakan Google Docs, seseorang akademisi hanya perlu memiliki satu salinan dokumen yang disimpan pada Google Web. Untuk melakukan kolaborasi, seseorang perlu memiliki dokumen pada Google Docs, lalu mengundang para rekan kerjanya sebagai kolaborator. Pemilik dokumen perlu mengalokasikan tugas untuk kolaborator sehingga masing-masing kolaborator tahu bagian mana yang seharusnya mereka kontribusikan (Mansor, 2012). Pada waktu mahasiwa melakukan kolaborasi membuat tulisan terdapat temuan tiga pola yang berkaitan dengan kualitas suatu tulisan, yaitu pola "outline," "example," dan "best-of-each", menunjukkan apakah kualitas suatu tulisan merupakan kolaborasi kerja yang menyeluruh, sebagian atau hanya poin tertentu saja (Wang, et al, 2015). Kualitas kerja dari kolaborasi antar anggota dapat terlihat mana anggota yang serius bekerja atau asal jadi. Dalam pengajaran bahasa
Inggris untuk membuat tulisan terdapat bermacam kendalayang dihadapi oleh mahasiswa. Dengan menggunakan aplikasi Google Docs, mahasiswa dapat melakukan kolaborasi dengan mahasiswa atau dosen untuk menghasilkan tulisan dalam bahasa Inggris yang berkualitas baik dalam jangka waktu yang cukup singkat. Mahasiswa yang mempunyai kendala penulisan akan mendapat masukan dari mahasiwa lain untuk masalah tata bahasa, ide tulisan dan aspek lain untuk membuat tulisan (Metilia \& Fitrawati, 2018). Berdasarkan paparan diatas, menggunakan Google Docs dapat menjadi alat (tool) untuk melakukan kolaborasi antar anggota dari suatu organisasi.

Permasalahan Ilmu Pengetahuan dan Teknnologi (Iptek) dalam pengetahuan dan pengelolaan aplikasi sistem informasi yang dialami oleh warga Kelurahan Sawah Baru wajib ditangani oleh Universitas Pembangunan Jaya (UPJ) yang berada di tempat lokasi berdekatan. UPJ dan Kelurahan Sawah Baru telah menjadi mitra dalam beberapa kegiatan pengabdian masyarakat. Untuk melakukan kegiatan ini telah tersusun dalam program pengem-bangan Iptek bagi masyarakat (UPJ, 2016). Masalah Iptek di bidang Teknologi Informasi ditangani oleh Program Studi Sistem Informasi. Berikut kajian pustaka yang menjadi acuan kegiatan. Pemanfaatan Teknologi Informasi bagi warga kelurahan untuk penguatan home industri dengan membuat promosi hasil-hasil usaha lewat website (Sasmito, et al, 2018). Pelatihan untuk mendukung administrasi RW (rukun warga) perumahan yang memanfaatkan aplikasi google docs, warga dapat dengan mudah menerima dan menggunakannya (Nopriadi \& Elisa, 2019). Berdasarkan hasil kajian pustaka tersebut dan studi analisis situasi atas permasalahan Iptek oleh dosen Program Studi Sistem Informasi bersama Sekretaris Kelurahan Sawah Baru, maka disepakati mengadakan kegiatan pelatihan sebagai solusinya. Tujuan kegiatan ini untuk meningkatkan pengetahuan dan memberikan keterampilan pengelolaan aplikasi sistem informasi kepada warga kelurahan Sawah Baru, Tangerang Selatan. 
Johannes Hamonangan Siregar, Chaerul Anwar, Marcello Sangaji

\section{METODE}

Dalam menyelesaikan permasalahan pengetahuan dan pengelolaan aplikasi sistem informasi dengan solusi melakukan kegiatan pelatihan dilakukan berdasarkan langkahlangkah yang ditunjukkan pada Gambar 2 berikut ini.

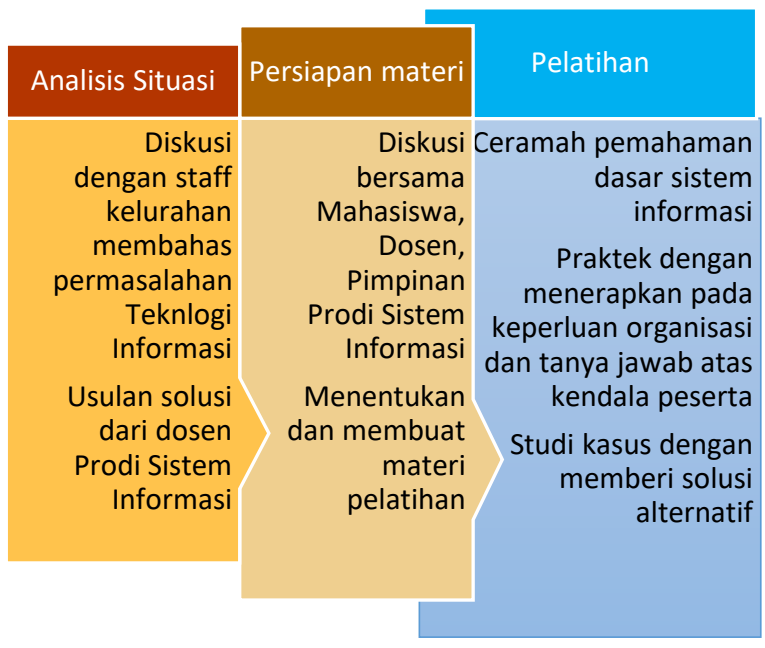

Gambar 2. Proses kegiatan pelatihan

Sebelum kegiatan pelatihan dilakukan telah dilakukan terlebih dahulu analisis situasi dan menelaah permasalahan mitra yaitu Kelurahan Sawah Besar. Diskusi bersama dengan sekretaris kelurahan untuk mewujudkan kegiatan ini membicarakan bentuk aktivitas pelatihan, tempat dan waktu pelaksanaan, peserta pelatihan serta materi pelatihan yang dibutuhkan dalam mencari solusi mitra. Peserta pelatihan diatur dan dipilih oleh sekretaris kelurahan yang menetapkan pemuda yang aktif dalam organisasi. Untuk bentuk aktivitas pelatihan, tempat, waktu pelaksanaan dan materi pelatihan diatur dan disiapkan oleh Program Studi Sistem Informasi UPJ.

Persiapan materi pelatihan dilakukan setelah disepakati untuk melaksanakan kegiatan pelatihan. Kepala Program Studi, dosen dan beberapa mahasiswa mendiskusikan rencana tersebut untuk menentukan materi pelatihan serta kebutuhan teknis untuk pelaksanaan pelatihan yang diadakan di kampus UPJ.
Setelah selesai persiapan materi, kegiatan pelatihan dilakukan dalam 3 tahap yang diuraikan sebagai berikut. Sebelum penyampaian materi dilakukan pre-tes untuk mengukur tingkat pengetahuan awal peserta tentang aplikasi sistem informasi.

Tahap pertama adalah kegiatan prioritas, dengan aktivitas pemberian materi melalui ceramah. Penyelesaian masalah dimulai dengan pemahaman kegunaan dan melatih operasi dasar pemakaian aplikasi sistem informasi. Peserta diharapkan paham dan mampu menjalankan operasi dasar dari penggunaan menjadi target pelatihan di tahap awal. Hal ini dikarenakan pelatihan awal tersebut dapat digunakan sebagai tahap pengenalan dan pengetahuan untuk pembelajaran dan pelatihan selanjutnya. Pada tahap ini dilakukan juga demonstrasi beberapa pengunaan teknologi aplikasi sistem informasi, seperti aplikasi WhatsApp dan Google Docs.

Tahap kedua adalah aktivitas praktek peserta meningkatkan pengetahuan dengan keterampilan mengelola informasi yang ada untuk diolah secara sederhana dengan memakai operasi tambahan yang ada dalam aplikasi. Pembelajaran pengelolaan aplikasi ini penting karena memiliki potensi yang bermanfaat yang dapat menjadi salah satu alat bantu dalam penyebaran informasi secara efisien dan cepat. Misalnya, isian formulir partisipasi peran serta untuk perayaan 17 Agustus atau isian formulir data anggota peserta penyuluhan dan pemeriksaan kesehatan, warga dapat menerima informasi dari staf kelurahan dengan cepat dan respon warga akan cepat dan tanggap dalam menyikapi informasi. Setelah peserta mendapatkan pemahaman cara pengelolaan aplikasi dengan baik dan akurat diharapkan informasi dapat tersebar luas dan akan meningkatkan kualitas layanan di kantor kelurahan.

Tahap ketiga adalah aktivitas konsultasi dan pemecahan masalah, kasus khusus yang akan dihadapi peserta dalam melakukan pengelolaan aplikasi. Dengan adanya penyediaan waktu untuk pembimbingan diharapkan peserta dapat melakukan tindak lanjut untuk keperluan dan tujuan yang 
Johannes Hamonangan Siregar, Chaerul Anwar, Marcello Sangaji Pelatihan Pengelolaan Aplikasi Sistem Informasi Bagi Warga Kelurahan Sawah Baru, Tangerang Selatan

ada bersama warga kelurahan atau staf kelurahan tanpa rasa kekuatiran akan masalah yang terjadi nantinya. Jika terjadi kendala, peserta dapat menyampaikan secepatnya pada dosen Program Studi Sistem Informasi untuk mendapatkan rekomendasi solusi.

\section{HASIL DAN PEMBAHASAN}

Proses awal perencanaan pelatihan ini diawali oleh pertemuan antara dosen Program Studi Sistem Informasi UPJ dan Sekretaris Kelurahan Sawah Baru pada akhir bulan Agustus 2018. Pertemuan tersebut membicarakan peranan sistem informasi, internet dan kondisi warga dengan layanan kelurahan, peran pemuda dan inisiasi untuk mengadakan pelatihan. Pertemuan berikut di bulan Desember, menetapkan rencana pelatihan, teknis pelaksanaan dan usulan materi pelatihan dari UPJ untuk warga Kelurahan Sawah Baru. Bersama mahasiswa yang akan terlibat kegiatan ini, dilakukan persiapan pelatihan dan teknis pelaksanaan.

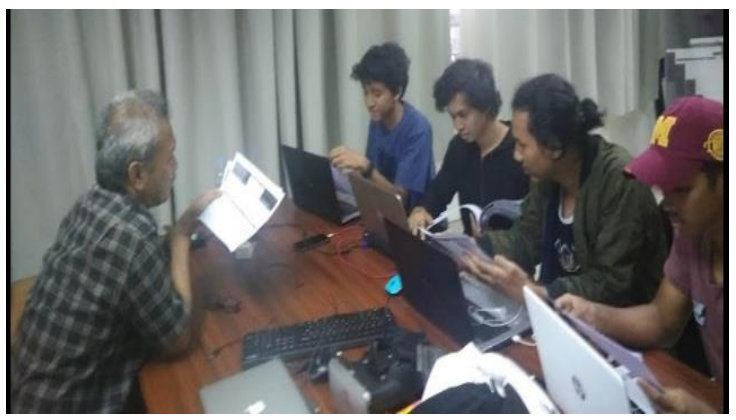

Gambar 3. Keikutsertaan mahasiswa dalam kegiatan menyusun materi

Pelaksanaan pelatihan dilakukan dalam rentang waktu Januari - Maret 2019, dengan 3 tahap aktivitas serta hasil yang didapatkan peserta dengan uraian sebagai berikut:

Tahap 1, dilaksanakan pada tanggal 7 Januari 2019, ceramah dan demonstrasi operasi dasar pemakaian aplikasi sistem informasi. Dari hasil pre tes peserta, pelatih memberikan materi dengan menyesuaikan diri pada kemampuan pengetahuan peserta. Pada tahap ini peserta mendapat dasar-dasar pengetahuan sistem informasi. Selama pemberian materi, peserta mendapat pertanyaan-pertanyaan langsung oleh pelatih berkaitan dengan materi yang telah diberikan. Jawaban peserta menunjukkan adanya pengetahuan meningkat. Bersamaan dengan itu respon peserta untuk mengelola sistem informasi meningkat, sehingga mempunyai motivasi untuk mengikuti lebih lanjut pelatihan. Peningkatan pengetahuan dilakukan dengan cara memperhatikan jawaban peserta atas pertanyaan yang diberikan, jika jawaban tidak benar akan dilakukan koreksi sehingga mendapat pemahaman yang tepat. Suasana pelatihan pada saat peserta memberikan jawaban dan koreksi untuk jawaban yang benar terlihat pada Gambar 4.

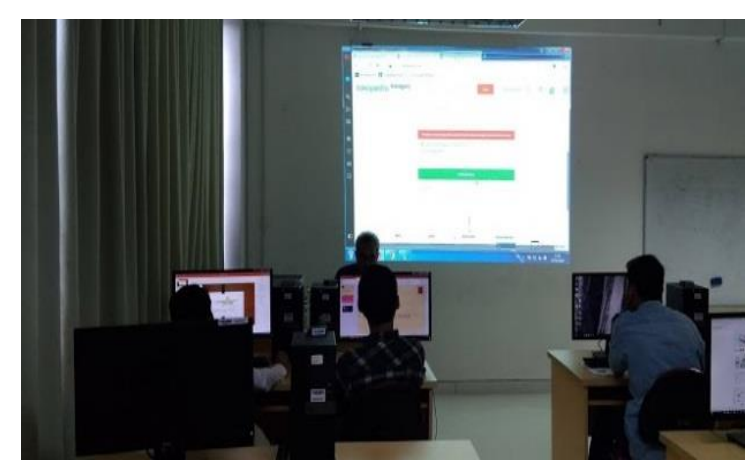

Gambar 4. Peserta menjawab pertanyaan sehu-bungan dengan materi yang telah diberikan

Tahap 2, dilaksanakan pada tanggal 14 Januari 2019, praktek menggunakan aplikasi sistem informasi. Peserta latihan untuk melakukan pengelolaan berdasarkan konsep dan pelatihan yang sudah diterima. Kreativitas dan ide-ide yang berhubungan dengan kegiatan organisasi digunakan dalam hal pengelolaan yang baik. Keterampilan menggunakan teknik pengelolaan aplikasi dilakukan oleh peserta waktu membuat suatu langkah prosedur sesuai dengan bidang organisasinya. Bagaimana informasi dapat tersusun dengan baik diperlihatkan oleh peserta sehingga memudahkan pencarian. Keterampilan pengelolaan aplikasi sistem informasi oleh peserta pelatihan tercapai dengan adanya ideide yang ditampilkan oleh peserta dalam diskusi praktek pengelolaan (Gambar 5). Dari diskusi sesama peserta untuk pemecahan masalah 
Johannes Hamonangan Siregar, Chaerul Anwar, Marcello Sangaji

Pelatihan Pengelolaan Aplikasi Sistem Informasi Bagi Warga Kelurahan Sawah Baru, Tangerang Selatan

menunjukkan adanya kolaborasi kerja untuk mencapai tujuan yang telah ditetapkan.

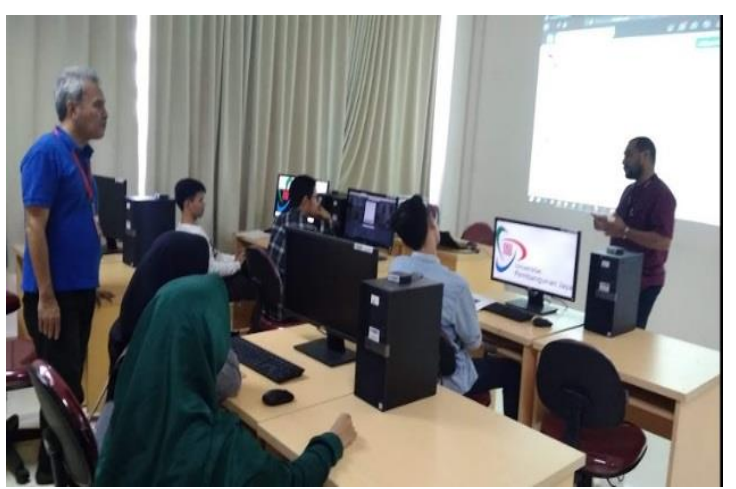

Gambar 5. Praktek dan tanya jawab berkaitan dengan pengelolaan aplikasi

Tahap 3. Tanggal 15 Januari - 15 Maret 2019, konsultasi dan pemecahan masalah peserta pelatihan yang berkaitan aplikasi sistem informasi yang digunakan. Pada tahap ini peserta menghubungi dosen yang melatih untuk mendapatkan solusi masalahnya. Kesulitan yang dialami peserta terjadi dalam hal sinkronisasi data dan komitmen antar anggota untuk melakukan kolaborasi. Pada tahap ini ada juga peserta yang menyatakan keinginannya menguasai aplikasi lain diluar materi pelatihan. Peserta tersebut membuat rencana pengembangan diri untuk mengikuti pelatihan teknis lanjutan.

Untuk mengukur hasil kegiatan dari aspek pengetahuan dilakukan pre tes dan pos tes. Peserta mendapatkan skor dalam nilai persen (\%) atas jawaban yang benar dari pertanyaan yang diberikan. Analisa data kuantitatif mengunakan rumus Gain (Hake, 1999), $g=\frac{\text { skor pos tes-skor pre tes }}{100-\text { skor pre tes }}$, menunjukkan ada tidaknya perolehan gain akan peningkatan pengetahuan dari peserta. Berdasarkan nilai gain terdapat 3 kategori perolehan perubahan yang menunjukkan peningkatan dari skor test yaitu Tinggi $(g \geq 0,7)$, Sedang $(0,3 \leq g<0,7)$ dan Rendah $(g<0,3)$. Pada kegiatan ini, hasil dari aspek pengetahuan ditunjukkan dengan banyaknya peserta mendapat peningkatan. Kategori gain dari berapa banyak dari 16 orang jumlah peserta dalam persen (\%) terlihat pada tabel berikut.

Tabel 1. Peningkatan Pengetahuan Peserta

\begin{tabular}{|l|c|l|}
\hline Kategori & Gain & Banyak Peserta \\
\hline Tinggi & $g \geq 0,7$ & 3 orang $(18,75 \%)$ \\
\hline Sedang & $0,3 \leq g<0,7$ & 9 orang $(56,25 \%)$ \\
\hline Rendah & $g<0,3$ & 4 orang $(25 \%)$ \\
\hline
\end{tabular}

Seluruh peserta $(100 \%)$ dari kegiatan ini mendapat peningkatan pengetahuan dengan kategori yang berbeda. Dilihat dari Tabel 1, jumlah peserta yang mendapat peningkatan pengetahuan dalam kategori rendah sebesar $25 \%$, peserta tersebut pernah melakukan pengelolaan aplikasi dan skor pos tes yang diperoleh $80 \%$ lebih. Peserta dalam kategori sedang sebesar $56,25 \%$, peserta tersebut aktif menggunakan aplikasi dan belum mampu melakukan pengelolaan aplikasi. Peserta dalam dalam kategori tinggi sebesar $18,75 \%$, peserta tersebut belum aktif dalam menggunakan aplikasi dan belum mampu melakukan pengelolaan aplikasi.

Untuk mengukur hasil kegiatan dari aspek keterampilan dilakukan pengamatan langsung dengan melihat hasil kerja peserta dalam melakukan pengelolaan. Peserta diberikan tugas untuk membuat dokumen dan spreadsheet secara kolaborasi dengan rekannya menggunakan aplikasi Google Docs. Pengamatan peserta dalam membuat tugas dilakukan dengan bantuan mahasiswa. Koreksi atas langkah pengelolaan yang tidak benar dengan segera memberitahukan sebab kesalahan. Dengan demikian peserta dapat segera mengingat langkah-langkah yang benar dengan cara mengulangi kembali langkah pengelolaan hingga benar. Hasil kegiatan dari aspek keterampilan didapatkan seluruh peserta (100\%) mampu melakukan pengelolaan aplikasi dengan benar.

Pelaksanaan kegiatan pelatihan ini dibantu oleh mahasiswa yang mempunyai minat dan kompetensi dalam masalah aplikasi sistem informasi. Dengan bantuan mahasiswa, peserta menjadi lebih mudah berkomunikasi menyatakan keinginannya akan aplikasi mana 
Johannes Hamonangan Siregar, Chaerul Anwar, Marcello Sangaji

Pelatihan Pengelolaan Aplikasi Sistem Informasi Bagi Warga Kelurahan Sawah Baru, Tangerang Selatan

yang diminati tanpa rasa segan, sehingga membuka kemungkinan kolaborasi antara peserta dan mahasiswa.

Peningkatan pengetahuan peserta yang tercapai melalui pelatihan ini sejalan dengan pernyataan bahwa organisasi dan individu juga harus diubah melalui pelatihan, pembelajaran dan rencana perubahan organisasi yang memungkinkan teknologi beroperasi dan berkembang (Laudon \& Laudon, 2015).

Dengan latar belakang peserta pelatihan yang berasal lingkungan yang sama yaitu berada dalam kelurahan yang sama, maka komunikasi antara peserta menjadi mudah. Selain itu peserta juga sudah mengenal kemampuan rekannya sehingga memudahkan untuk bekerja sama, saling mendukung untuk mencapai tujuan mempunyai keterampilan yang berguna bagi organisasinya. Ketercapaian keterampilan ini berkaitan dengan teori perkembangan komunitas yang menyatakan kapasitas sesorang dalam komunitas dibangun ketika ia mendorong atau mengajar orang lain untuk mencapai keterampilan (Phillips \& Pittman, 2009). Dari keterampilan yang dimiliki para peserta dan kemampuan kolaborasi kerja antar peserta, akan efektif dalam melancarkan informasi dan mendistribusikan program pembangunan pemerintah (Pusat Humas Kementerian Perdagangan RI, 2014).

\section{SIMPULAN}

Pelatihan pengelolaan aplikasi sistem informasi bagi warga Kelurahan Sawah Baru yang dilaksanakan telah mencapai tujuan yaitu meningkatkan pengetahuan dan memberikan keterampilan pengelolaan aplikasi sistem informasi. Hasil kegiatan ini dari aspek pengetahuan, peserta mendapat peningkatan dalam kategori yang berbeda. Dari aspek keterampilan, peserta mampu melakukan pengelolaan aplikasi dengan benar. Peningkatan pengetahuan untuk mengelola aplikasi dengan benar, akan membantu peserta dalam mengeluarkan ide-idenya untuk mencari solusi dari masalah yang mungkin terjadi dalam pengelolaan. Dengan melakukan praktek aktivitas kolaborasi selama pelatihan ini, maka keterampilan pengelolaan dapat dicapai oleh peserta melalui kerjasama dan berbagi ide sesama peserta atau mahasiswa yang terlibat dalam kegiatan ini.

\section{UCAPAN TERIMA KASIH}

Kepada Lembaga Penelitian dan Pengabdian Masyarakat Universitas Pembangunan Jaya atas dana hibah untuk pelaksanaan kegiatan, sesuai dengan surat Perjanjian Pelaksanaan Hibah Pengabdian Kepada Masyarakat Tahun Anggaran 2018/2019, No: 007/PER-P2M/UPJ/11.18. Kepada warga dan pimpinan Kelurahan Sawah Besar yang menjadi mitra kegiatan dan partisipasinya.

\section{DAFTAR PUSTAKA}

Asosiasi Penyelenggara Jasa Internet Indonesia (APJII) (2018). SURVEI APJII : Penetrasi Internet di Indonesia Capai 143 Juta Jiwa, Buletin APJII Edisi 22 Maret 2018.

Badan Pusat Statistik (BPS) (2017). Statistik Kesejahteraan Rakyat Kota Tangerang Selatan 2017. BPS Kota Tangerang Selatan.

Hake, R. R. (1999). Analyzing Change/Gain Scores, Department of Physics, Indiana University, Woodlands, CA

Laudon, K. C., \& Laudon, J. P. (2015). Management information systems: managing the digital firm, 15th Edition. Pearson Education. Harlow, England. DOI:https://doi.org/10.1016/j.ijinfomg t.2003.12.006

Mansor, A. Z. (2012). Google Docs as a Collaborating Tool for Academicians. Procedia - Social and Behavioral Sciences, 59 (2012), 411-419. DOI: https://doi.org/10.1016/j.sbspro.2012.0 9.295

Metilia, T., \& Fitrawati. (2018). Using Google Docs for Collaborative Writing in Teaching Writing Descriptive Text to 
English Department Students. Journal of English Language Teaching, 7(1), 194-200.

Nopriadi \& Elisa E. (2019). Pelatihan Office Berbasis Cloud Sebagai Pendukung Administrasi RW di Perumahan Pondok Rhabayu Kota Batam. Kaibon Abhinaya : Jurnal Pengabdian Masyarakat, $1(2), 48$ - 52. DOI: $10.30656 /$ ka.v1i2.1541

Phillips, R., \& Pittman, R. H. (2009). An Introduction to Community Development. New York: Routledge.

Pusat Humas Kementerian Perdagangan RI. (2014). Panduan Optimalisasi Media Sosial untuk Kementerian Perdagangan RI. Jakarta: Pusat Hubungan Masyarakat Kementerian Perdagangan Republik Indonesia

Sasmito, G. W., Apriliani, D. \& Nishom M., (2018). Pemanfaatan Teknologi Informasi untuk Penguatan Home Industri di Kelurahan Pesurungan Lor, Kota Tegal. Jurnal Pengabdian Masyarakat Teknik (JPMT), 1(1), 21-25. DOI: https://dx.doi.org/10.24853/jpmt.1.1.2 $1-25$

Universitas Pembangunan Jaya (UPJ) (2016). Pedoman Pelaksanaan Penelitian dan Pengabdian kepada Masyarakat di UPJ. Tangerang Selatan: Lembaga Penelitian dan Pengabdian Masyarakat Universitas Pembangunan Jaya

Wang, D., Olson, J. S., Zhang, J., Nguyen, T., \& Olson, G. M. (2015). How Students Collaboratively Write using Google Docs. IConference 2015 Proceedings, 1-5. Diakses dari http://hdl.handle.net/2142/73736 